\title{
How should Creationism and Intelligent Design be Dealt with in the Classroom?
}

\author{
MICHAEL J. REISS
}

Until recently, little attention has been paid in the school classroom to creationism and almost none to intelligent design. However, creationism and possibly intelligent design appear to be on the increase and there are indications that there are more countries in which schools are becoming battlegrounds over them. I begin by examining whether creationism and intelligent design are controversial issues, drawing on Robert Dearden's epistemic criterion of the controversial and more recent responses to and defences of this. I then examine whether the notion of 'worldviews' in the context of creationism is a useful one by considering the film March of the Penguins. I conclude that the 'worldviews' perspective on creationism is useful for two reasons: first it indicates the difficulty of using the criterion of reason to decide whether an issue is controversial or not; secondly, it suggests that standard ways of addressing the diversity of student views in a science classroom may be inadequate. I close by examining the implications of this view for teaching in science lessons and elsewhere, for example in religious education lessons and citizenship lessons and at primary level where subject divisions cannot be made in so clear-cut a manner.

\section{THE IMPORTANCE OF CREATIONISM FOR SCHOOLS}

Creationism exists in a number of different versions, but something like $50 \%$ of adults in Turkey, $40 \%$ in the USA and $15 \%$ in the UK reject the theory of evolution: they believe that the Earth came into existence as described by a literal (fundamentalist) reading of the early parts of the Bible or the Qu'ran and that the most that evolution has done is to change species into closely related species (Miller et al., 2006; Lawes, 2009). For a creationist it is possible, for example, that the various species of deer had a common ancestor but this is not the case for deer, bears and squirrels_ — still less for monkeys and humans, for birds and reptiles or for fish and fir trees.

Allied to creationism is the theory of intelligent design. While many of those who advocate intelligent design have been involved in the creationism movement, to the extent that the US courts have argued that the country's First Amendment separation of religion and the State precludes its teaching in public schools (Moore, 2007), intelligent design can claim to be a theory that simply critiques evolutionary biology rather than advocating or requiring religious faith. Those who promote intelligent design typically come from a conservative faith-based position. However, in many of their arguments, they make no reference to the scriptures or a deity but argue that the intricacy of what we see in the natural world, including at a sub-cellular level, provides strong evidence for the existence of an intelligence behind this (e.g. Behe, 1996; Dembski, 1998; Johnson, 1999). An undirected process, such as natural selection, is held to be inadequate. 
Until recently little attention has been paid in the school classroom to creationism and almost none to intelligent design. However, creationism appears to be on the increase, and there are indications that there are more countries in which schools are becoming battlegrounds for the issue. For example, while the USA has had several decades of legal battles about the place of creationism and (more recently) intelligent design in schools (Moore, 2007), school-based conflicts over these issues are becoming more frequent in a range of other countries (Graebsch and Schiermeier, 2006; Chinsamy and Plagányi, 2007; Mercer, 2007; Kutschera, 2008). In 2006 the organisation Truth in Science sent a free resource pack to the Head of Science in each UK secondary school and sixth form college. As stated on the organisation's website: 'The Truth in Science resource pack describes and critiques Darwin's theory of evolution on a scientific basis. It also shows scientific evidence suggesting that the living world is intelligently designed. ${ }^{1}$ At about the same time, many scientists and educators in a number of countries received copies of the first volume of what promises to be a massive seven volume series titled The Atlas of Creation. Authored by Harun Yahya (the pen name of Adnan Okta) these lavish books (volume 1 is 800 pages in length and weighs $5.4 \mathrm{~kg}$ ) present a creationist critique of the fossil evidence for evolution.

These several events have led to a growth in the science education literature examining creationism and/or intelligent design (Jones and Reiss, 2007; Allgaier, 2008; Hokayem and BouJaoude, 2008; Williams, 2008; Alexakos, 2009). Nor does the debate seem about to fade away. There was consternation in the UK science education community when, in December 2009, many secondary school and higher education libraries received a complimentary copy of the 2009 book by Stephen Meyer et al. titled Explore Evolution, which, in the words of its website, sets out:

to examine the scientific controversy about Darwin's theory, and in particular, the contemporary version of the theory known as neo-Darwinism. Whether you are a teacher, a student, or a parent, this book will help you understand what Darwin's theory of evolution is, why many scientists find it persuasive, and why other scientists question the theory or some key aspects of it. ${ }^{2}$

The school classroom, of course, is not the only place where creationism might be addressed. There is the beginnings of a literature on the way that museums present the issue of evolution (Bennett, 2004; Scott, 2007) and many of us also learn about creationism and evolution through radio and TV programmes, by reading popular science books (authored by Richard Dawkins, Stephen Jay Gould and others) and by other means. Nevertheless, there is a particular need to address the issue of whether, and if so how, schools might address the issue of creationism. I am especially interested in the education provided to those for whom education is mandatory. I am also concerned to make suggestions that can be implemented in today's classrooms. Since, as discussed further below, countries differ considerably in the extent to which, even whether at all, they permit discussion of religion in their classrooms this means that suggestions cannot be universal. I concentrate on the UK, though argue that in fact there are fewer differences between countries in this regard than is commonly suspected.

\section{ARE CREATIONISM AND INTELLIGENT DESIGN CONTROVERSIAL ISSUES?}


It may seem somewhat surprising to ask if creationism and intelligent design are controversial issues given the furore that regularly surrounds them in many countries in the courts, in the media and in schools but the answer to the question depends on one's precise understanding of the term 'controversial issue'. Much of the recent literature in education on controversial issues hinges on the work of Robert Dearden (1981/1984).

Dearden after, somewhat uncontroversially, rejecting logical positivism as a basis for curriculum design, points out that 'what is 'controversial' may itself be a matter of controversy' (Dearden, 1981/1984, p. 85). He then goes on propose an epistemic criterion of the controversial in which 'a matter is controversial if contrary views can be held on it without those views being contrary to reason' (p. 86). He points out that several possible kinds of controversial issue may be distinguished: 'cases where we simply have insufficient evidence to settle the matter, though in principle there is no reason why it should not be settled as more or better evidence becomes available' (ibid.); 'where consideration-making criteria are agreed but the weight to be given them is not' (ibid.); 'where there is no agreement even on the criteria as to what will count' (ibid.) and, finally, 'where not just individual criteria but whole frameworks of understanding are different' (p. 87). This four-fold categorisation has been valuably extended with specific reference to the teaching of controversial issues in school science by Ralph Levinson (2006).

However, Dearden's epistemic criterion of the controversial is not the only one. Indeed, standard works on the teaching of controversial issues (e.g. Wellington, 1986; Claire and Holden, 2007; Hess, 2009) provide broader, often fuzzier, definitions. Here, for instance, is one from the opening chapter of a book titled The Challenge of Teaching Controversial Issues authored by two academics:

In general terms a controversial issue is one in which

- the subject/area is of topical interest

- there are conflicting values and opinions

- there are conflicting priorities and material interests

- emotions may become strongly aroused

- the subject/area is complex (Claire and Holden, 2007, pp. 5-6).

There is, of course, a long tradition of writing in education on controversial issues and examining precisely what it is that makes an issue controversial (e.g. Stradling, 1984; Stradling et al., 1984; Bridges, 1986; McLaughlin, 2003). Recently, Michael Hand (2008) has defended and extended Dearden's epistemic criterion. There is much in Hand's position that is attractive. He argues that 'What distinguishes teaching-assettled from teaching-as-controversial (or directive from nondirective teaching) is not a pedagogical method or style, but the willingness of the teacher to endorse one view on a matter as the right one' (Hand, 2008, p. 213) and points out that 'The English word "controversial" means simply "disputed", and the existence of dispute is an unpromising criterion for what should be taught nondirectively' (p. 214). Hand then procedes to critique curriculum materials, even guides, that take too broad a view of 'controversy'. For example, he points out topics such as bullying and racism are 
frequently described as controversial which hardly fits with standard advice given in such material and guides that teachers should teach controversial issues in a balanced manner, giving equal weight to opposing views.

And yet I am not entirely persuaded by Hand's arguments. For a start he relies on the premise that "that the central aim of education is to equip students with a capacity for, and inclination to, rational thought and action' (p. 218). This seems to me quite a narrow view. I cannot here review all the arguments as to the aims of education (cf. Marples, 1999) but Hand seems to privilege rationality. I prefer a combination of autonomy, human flourishing and justice and have attempted to relate these to the specific aims of school science education (Reiss, 2007). However, this is perhaps something of a side issue, for Hand maintains that 'By enabling young people to think and act rationally we optimize their prospects of leading flourishing lives' (Hand, 2008, p. 218). The more important issue concerns the issue of who decides whether an issue is controversial and how problematic such a decision is.

As is generally accepted (e.g. O'Brien, 2006) there are two major epistemological families for knowledge that is not a priori: those centred on perceiving the world for ourself and those centred on the testimony of others. There is obviously not the space here to go into a major discussion of each of these but it is sufficient for my purposes to note that in both cases knowledge, for all that it may be reliable, has an element of provisionality. Of course, some knowledge is more provisional than others. A useful distinction in science is made by Imre Lakatos (1978) who argued that scientists work within research programmes. A research programme consists of a set of core beliefs surrounded by layers of less central beliefs. Scientists are willing to accept changes to these more peripheral beliefs so long as the core beliefs can be retained. So, in biology, we might see in contemporary genetics a core belief in the notion that development proceeds via a set of interactions between the actions of genes and the influences of the environment. At one point, it was thought that the passage from DNA to RNA was unidirectional. Now we know (reverse transcriptase, etc.) that this is not always the case. The core belief (that development proceeds via a set of interactions between the actions of genes and the influences of the environment) remains unchanged but the less central belief (that the passage from DNA to RNA is unidirectional) is modified. However, even core beliefs can sometimes be changed (Kuhn's famous point about crises in science that lead to shifts in paradigms).

The point of all this is that unless one is prepared to define 'controversy' at a particular moment in time and place in space and for a particular audience, it is clear that any attempt simply to divide issues into 'controversial' and 'non-controversial' is unlikely to succeed for all but the most mundane points of possible contention: there are degrees of controversy and, as Hand and many others acknowledge, what is controversial for one group may not be controversial for another. Indeed, creationism provides a useful illustration of this point as it is controversial neither for scientists nor for creationists_— though for opposing reasons.

The scientific understanding of biodiversity is far from complete but the narrative is a powerful one. Around 3.5 billion years ago, possibly earlier, life evolved on Earth. Very little is known with any great confidence about this early history (Maynard Smith and Szathmary, 2000); far less than is known, for example, about how stars form, grow and die. By the time of the earliest fossils, life was unicellular and bacteria-like. Over the next three and a half billion years, the workings of natural 
selection, possibly aided by other mechanisms (genetic drift, etc.), eventually resulted in the 10 million or so species, including our own, that we find today.

The scientific worldview is materialistic in the sense that it is neither idealistic nor admits of non-physical explanations (here, 'physical' includes such things as energy and the curvature of space as well as matter). There is much that remains unknown about evolution. How did the earliest self-replicating molecules arise? What caused membranes to exist? How key were the earliest physical conditions - temperature, the occurrence of water and so forth? But the scientific presumption is either that these questions will be answered by science or that they will remain unknown. Although some scientists might (sometimes grudgingly) admit that science cannot disprove supernatural explanations, scientists do not employ such explanations in their work (the tiny handful of seeming exceptions only attest to the strength of the general rule).

Whereas there is only one mainstream scientific understanding of biodiversity, there are a considerable number of religious ones. Many religious believers are perfectly comfortable with the scientific understanding, either on its own or accompanied by a belief that evolution in some sense takes place within God's holding (compass or care), whether or not God is presumed to have intervened or acted providentially at certain key points (e.g. the origin of life or the evolution of humans). But many other religious believers adopt a more creationist perspective or that of intelligent design (Reiss, 2008a).

Most of the literature on creationism (and/or intelligent design) and evolutionary theory puts them in stark opposition. Evolution is consistently presented in creationist books and articles as illogical (e.g. natural selection cannot, on account of the second law of thermodynamics, create order out of disorder; mutations are always deleterious and so cannot lead to improvements), contradicted by the scientific evidence (e.g. the fossil record shows human footprints alongside animals supposed by evolutionists to be long extinct; the fossil record does not provide evidence for transitional forms), the product of non-scientific reasoning (e.g. the early history of life would require life to arise from inorganic matter - a form of spontaneous generation rejected by science in the $19^{\text {th }}$ Century; radioactive dating makes assumptions about the constancy of natural processes over aeons of time whereas we increasingly know of natural processes that affect the rate of radioactive decay), the product of those who ridicule the word of God, and a cause of a whole range of social evils (from eugenics, Marxism, Nazism and racism to juvenile delinquency) - e.g. Whitcomb and Morris (1961), Watson (1975), Hayward (1985), Baker (2003), Parker (2006) and articles too many to mention in the journals and other publications of such organisations as Answers in Genesis, the Biblical Creation Society, the Creation Science Movement and the Institute for Creation Research.

By and large, creationism has received similarly short shrift from those who accept the theory of evolution. In a fairly early study the philosopher of science Philip Kitcher argued that 'in attacking the methods of evolutionary biology, Creationists are actually criticizing methods that are used throughout science' (Kitcher, 1982, pp. 4-5). Kitcher concluded that the flat-earth theory, the chemistry of the four elements, and mediaeval astrology 'have just as much claim to rival current scientific views as Creationism does to challenge evolutionary biology' (Kitcher, 1982, p. 5). An even more trenchant attack on creationism is provided by geologist Ian Plimmer whose 
book title Telling Lies for God: Reason vs Creationism (Plimmer, 1994) shows the line he takes.

Many scientists have defended evolutionary biology from creationism - see, for example, the various contributions in Selkirk and Burrows (1987), Good et al. (1992) and Jones and Reiss (2007) and an increasing number of agreed statements by scientists on the teaching of evolution (e.g. Interacademy Panel on International Issues, 2006). The main points that are frequently made are that evolutionary biology is good science since not all science consists of controlled experiments where the results can be collected within a short period of time; that creationism (including 'scientific creationism') isn't really a science in that its ultimate authority is scriptural and theological rather than the evidence obtained from the natural world; and that an acceptance of evolution is fully compatible with a religious faith, an assertion most often made in relation to Christianity (e.g. Southgate et al., 2005) whilst more obviously true of many other religions - including Hinduism, Buddhism and Judaism - and probably generally rather less true of Islam (Mabud, 1991; Negus, 2005; Edis, 2007).

\section{WORLDVIEWS}

In World Views: From fragmentation to integration, Diederik Aerts et al. (1994) state that 'A world view is a coherent collection of concepts and theorems that must allow us to construct a global image of the world, and in this way to understand as many elements of our experience as possible' (p. 17). In science education the notion of worldviews (whether one word or two) is increasingly being employed. For example, in the edited volume Science, Worldviews and Education (Matthews, 2009), a number of philosophers, scientists and science educators use the thinking behind worldviews to explore a range of issues including whether science itself is a worldview and whether science can test supernatural worldviews. The term has recently been explored as a way of helping conceptualise why, despite the best efforts of many science educators, so few student leave their schooling with the sort of scientific understanding and disposition that most science teachers which they had. The principal conclusion is that school science fails to enable most students to see the world from a scientific perspective.

I aim to explicate the notion of 'worldviews' in the context of creationism by considering the film March of the Penguins (Reiss, 2009). March of the Penguins is a 2005 National Geographic feature film. It runs for approximately 85 minutes and is accompanied by a book available in the original 2005 French and a 2006 translation into English (Jacquet, 2006). For a two-minute trailer see the official website (Warner Independent Pictures, 2010) which gives a good impression of the exceptional footage in the film. The trailer also includes the words of Morgan Freeman that begin the English (USA) film: 'In the harshest place on Earth, love finds a way. This is the incredible true story of a family's journey to bring life into the world'.

The film has been an exceptional success. It won an Academy Award (an 'Oscar') in 2006 for Best Documentary Feature, was awarded Best Documentary at the 2005 National Board of Review and was nominated for Best Documentary in 2005 by the Broadcast Film Critics Association. In terms of revenue it the most successful nature film in American motion picture history, taking US\$77.4m at the box office and 
scoring $94 \%$ on the Tomatometer (Tomatometer, 2009). The reasons for the success of March of the Penguins are no doubt several: the photography is phenomenal; the emperor penguin's story is extraordinary; the adults are elegant; the chicks are irredeemably cute as they look fluffy, feebly wave their little wings and learn to walk; the way in which the birds survive the Antarctic winter is awesome; the plaintive cries of mothers who lose their chicks in snow storms are heartrending. But one perhaps unexpected reason is that the film has been a great success among the Christian right.

For example, if one enters " "march of the penguins" Christian' into Google, at the time of writing (1 January 2010) one finds 47,000 hits. Second of these is a review of the film by Mari Helms (n.d.) on ChristianAnswers. Net, which describes itself as 'a mega-site providing biblical answers to contemporary questions for all ages and nationalities with over 45-thousand files' (ChristianAnswers.Net, 2009). After a fairly detailed summary of the subject matter of the film, and reassurance that viewers won't find much in the film to be objectionable, the review goes on to discuss the lessons that the film has to teach about love, perseverance, the existence of God and friendship/commraderie (sic). An extended quotation from the review [underlinings indicate hyperlinks to other pages on the ChristianAnswers.Net website] illustrates the presuppositions of the author:

'March of the Penguins' has lessons to teach about:

'LOVE': According to the film, the penguins take this tremendous journey for 'love' and to find a mate and reproduce. The dedication, cooperation, and affection are exemplary between the pair.

PERSEVERANCE: We could learn a lot about perseverance from Emperor penguins. I was quickly reminded of the ant in Proverbs 6:7-8 'It has no commander, overseer or ruler, yet it stores its provisions in summer and gathers its food at harvest.' No one is reminding these penguins what to do; they know what to do, and they do it. They are prepared, persistent and committed, much like we are called to be as witnesses for Jesus Christ. 1 Peter 4:15 'Always be prepared to give an answer to everyone who asks you to give the reason for the hope that you have.'

The penguins endure treacherous conditions, yet they continue on their journey, focusing on what lies ahead (new life). It may be a bit of a stretch, but I thought of what we, as Christians have to endure to get what lies ahead for us (eternal life). Philippians 3:14 'I press on toward the goal to win the prize for which God has called me heavenward in Christ Jesus.'

THE EXISTENCE OF GOD: One year in the life of an Emperor penguin is a great indication of the existence and character of God. Romans 1:20 'For since the creation of the world God's invisible qualities - his eternal power and divine nature - have been clearly seen, being understood from what has been made, so that men are without excuse.' He is absolutely perfect! Every detail has been taken into account, and every provision has been made. Witnessing all the love and care that He must have put into creating the penguins is small compared to what He put into creating us. Matthew 6:26 'Look at the birds of the air; they do not sow or reap or store away in barns, and yet your heavenly Father feeds them. Are you not much more valuable than they?' Leaving the theater, I was more in awe and in love with my Creator (Helms, n.d.). 
In the four-fold framework of Ian Barbour (1990), who explores how science and religion can be understood to relate, this quotation manifests an integrated relationship (as opposed to one of conflict, of independence or of dialogue). The worldview is one in which it is straightforward to read from penguin behaviour to human behaviour though it is worth noting that the argument is neither entirely anthropomorphic (where non-human behaviour is interpreted as if it was the behaviour of humans) nor one in which the natural world is seen as the source of instruction as to how humans should behave. Rather, it is scripture that has primacy; the natural world is held up not so much as a model for us to imitate but as an illustration of how the natural world can manifest that which God wishes for humanity.

Such a reading of nature in March of the Penguins is facilitated by the wonderful photography which enables the viewer to read into the footage as much as (s)e reads from it. Indeed, Luc Jacquet has been quoted as saying 'My intention was to tell the story in the most simple and profound way and to leave it open to any reading' (Miller, 2005). So I, with a $\mathrm{PhD}$ and post-doc in evolutionary biology (though also a priest in the Church of England with a conventional, albeit non-fundamentalist, Christian faith), can see it as a manifestation of the extraordinary ability of natural selection over millions of years to enable an organism to survive and reproduce in the most inhospitable of environments while others can see it as a clear manifestation of Intelligent Design: 'To think that natural selection or even the penguins themselves could come up with the idea to migrate miles and miles multiple times each year without their partner or their offspring is a bit insulting to my intellect. How great is our God!' (Gold, 2005) Gold's conclusion is despite the fact that the film begins by talking about how Antarctica used to be covered in tropical forest before it drifted South and then says of the emperor penguins 'For millions of years they have made their home on the darkest, driest, windiest and coldest continent on earth' and is despite the fact that the film relates how females aggressively compete for males and depicts the way in which mothers who have lost their chicks may attempt to steal other chicks. The film is also honest, I presume to the chagrin of some conservatives, about the fact that most emperor penguins are faithful to their partners for only one season; in the jargon of those who study animal behaviour, emperor penguins are serially monogamous, unlike, for example, swans which typically pair for lifethough extra-pair copulations do occur in swans (Barash and Lipton, 2001).

The 'worldviews' perspective on creationism is useful for two reasons: first it indicates the difficulty of using the criterion of 'reason' to decide whether an issue is controversial or not since, without embracing epistemological relativism, it highlights the importance of perspective in these matters - for many people, the position from which one can view dispassionately is so distant that one cannot from there see in much detail. Secondly, as I shall go on to argue, it suggests that standard ways of addressing the diversity of student views in a science classroom may be inadequate.

\section{DEALING WITH CREATIONISM AND INTELLIGENT DESIGN IN THE SECONDARY SCIENCE CLASSROOM}

Few countries have produced explicit guidance as to how schools might deal with the issues of creationism or intelligent design in the science classroom. One country that 
has is England. In the summer of 2007, after months of behind-the-scenes meetings and discussions, the then DCSF (Department of Children, Schools and Families) Guidance on Creationism and Intelligent Design received Ministerial approval and was published (DCSF, 2007). The Guidance points out that the use of the word 'theory' in science (as in 'the theory of evolution') can mislead those not familiar with science as a subject discipline because it is different from the everyday meaning (i.e. of being little more than an idea). In science the word indicates that there is a substantial amount of supporting evidence, underpinned by principles and explanations accepted by the international scientific community. The Guidance goes on to state: 'Creationism and intelligent design are sometimes claimed to be scientific theories. This is not the case as they have no underpinning scientific principles, or explanations, and are not accepted by the science community as a whole' (DCSF, 2007). The Guidance then goes on to say:

Creationism and intelligent design are not part of the science National Curriculum programmes of study and should not be taught as science. However, there is a real difference between teaching ' $\mathrm{x}$ ' and teaching $a b o u t$ ' $\mathrm{X}$ '. Any questions about creationism and intelligent design which arise in science lessons, for example as a result of media coverage, could provide the opportunity to explain or explore why they are not considered to be scientific theories and, in the right context, why evolution is considered to be a scientific theory (DCSF, 2007).

This seems to me a key point and one that is independent of country, whether or not a country permits the teaching of religion (as in the UK) or does not (as in France, Turkey and the USA). Many scientists, and some science educators, fear that consideration of creationism or intelligent design in a science classroom legitimises them. For example, the excellent book Science, Evolution, and Creationism published by the US National Academy of Sciences and Institute of Medicine asserts 'The ideas offered by intelligent design creationists are not the products of scientific reasoning. Discussing these ideas in science classes would not be appropriate given their lack of scientific support' (National Academy of Sciences and Institute of Medicine, 2008, p. $52)$.

As I have argued (Reiss, 2008b), I agree with the first sentence of this quotation but disagree with the second. Just because something lacks scientific support doesn't seem to me a sufficient reason to omit it from a science lesson. When I was taught physics at school, and taught it extremely well in my view, what I remember finding so exciting was that we could discuss almost anything providing we were prepared to defend our thinking in a way that admitted objective evidence and reasoned argument. Nancy Brickhouse and Will Letts (1998) have argued that one of the central problems in science education is that science is often taught 'dogmatically'. With particular reference to creationism they write:

Should student beliefs about creationism be addressed in the science curriculum? Is the dictum stated in the California's Science Frameworks (California Department of Education, 1990) that any student who brings up the matter of creationism is to be referred to a family member of member of the clergy a reasonable policy? We think not. Although we do not believe that what people call 'creationist science' is good science (nor do scientists), to place a gag order on teachers about the subject entirely seems 
counterproductive. Particularly in parts of the country where there are significant numbers of conservative religious people, ignoring students' views about creationism because they do not quality as good science is insensitive at best (Brickhouse and Letts, 1998, p. 227).

More recently, Thomas Nagel (2008) has argued that so-called scientific reasons for excluding intelligent design (ID) from science lessons do not stand up to critical scrutiny (cf. Koperski, 2008). With reference to the USA he concludes:

I understand the attitude that ID is just the latest manifestation of the fundamentalist threat, and that you have to stand and fight them here or you will end up having to fight for the right to teach evolution at all. However, I believe that both intellectually and constitutionally the line does not have to be drawn at this point, and that a noncommittal discussion of some of the issues would be preferable (Nagel, 2008, p. 205).

\section{DEALING WITH CREATIONISM AND INTELLIGENT DESIGN ELSEWHERE IN THE CURRICULUM}

Of course, science lessons are not the only place where teaching about creationism and intelligent design might take place in the curriculum. One might also expect them to be addressed in religious education (RE) lessons, for countries that have such lessons. Indeed, my experience from talking with science teachers and being a member of the Biotutor Discussion List is that this is a common response from science teachers - 'leave it to the RE teachers to deal with and let us get on with teaching the science'.

In England, the DCSF and QCA (Qualifications and Curriculum Authority) published a non-statutory national framework for RE and associated teaching units that include a unit asking 'How can we answer questions about creation and origins?' (QCA, 2006). The unit focuses on creation and the origins of the universe and human life, as well as the relationships between religion and science. This is a carefully written 23 page guide. Along with its non-evaluative stance towards the various positions, what strikes me as a science educator is the high expectations of students it has. For example, in answer to the question 'Is the universe designed? Who could have designed it?', it is suggested that teachers of 13-14 year-olds should:

Give the pupils opportunities to explore, through a website, DVD or written text (see 'Resources'), a range of different answers to these questions, including answers given by members of different faiths. These answers should include the views of creationists, evolutionists, advocates of intelligent design and philosophers of religion, such as Anselm, Thomas Aquinas, Blaise Pascal and Francis Bacon (QCA, 2006, p. 16).

We can note that this non-evaluative (some might say non-discriminatory; many scientists and not a few science educators would say mealy-mouthed) stance towards the various positions has taken place in a context where, since the late 1950s in England and Wales, advocates of religious education in schools have abandoned a form of religious education where the inculcation of Christianity was a central aim and in which Christianity was often presumed to be the sole framework within which 
life found meaning and moral direction. Nowadays a more pluralist vision is preferred (e.g. Jackson, 2004) in which students are enabled to develop, clarify and refine their own views about matters religious. This is very different to the position in science where the presumption, whether implicit or stated, is nearly always that the scientific understanding of the world is either a valid one or the valid one. (For fairly extreme articulations of this see Peter Atkins (1992), which makes Richard Dawkins' pronouncements on religion seem fairly middle of the road, and Martin Mahner and Mario Bunge (1996).)

Another place in schools where creationism and intelligent design might be addressed is in citizenship lessons. As Mark Halstead and Mark Pike (2006) argue, one of the aims of citizenship education might be to produce autonomous, critically reflective citizens (cf. Osler and Starkey, 2005). Halstead and Pike point out that if this is the case, there are three areas where reflection is needed: the nature and obligations of citizenship and on its implications for personal development; on the needs of society, 'particularly, for example, those needs that arise from the increasing diversity in society (e.g. challenging racism and religious prejudice)' (p. 39); and on dilemmas and controversies relating to citizenship. The second and third of these areas, in particular, are ones where teaching about creationism and intelligent design might not only be appropriate but helpful in addressing these issues from a somewhat different, broader, perspective than those likely in science and religious education lessons.

Finally, I should note that the distinction between science lessons, religious education lessons and citizenship education lessons, while it may hold at secondary level with subject-specific teaching rather breaks down at primary level where a pupil generally has the same teacher for most or all lessons. From an epistemological point of view this is both the strength and potential weakness of primary teaching. Teaching in the primary school has the potential to make links between subjects with greater ease than is generally the case at secondary school, precisely because the one teacher is responsible for such a diversity of subjects. At the same time, a primary teacher is unlikely to know each subject in as much depth as a secondary specialist and therefore there is a greater likelihood that subject-specific differences may be elided. This suggests that it may be particularly important for primary teachers to be explicit as to whether they are helping their pupils to understand an issue from the perspective of science, of history, of religion or whatever.

\section{CONCLUSION}

The title of this paper- 'How should creationism and intelligent design be dealt with in the classroom?'-is a straightforward question. As I have argued, though, the answer depends, at least to a certain extent, on the subject matter of the lessons (e.g. science, religious education, citizenship) and the age range of one's class (primary, secondary), in addition to the country one is in. However, whatever the subject matter and age range of a class, there is much to be said for a teacher bearing in mind that for some students, creationism and intelligent design are likely to be sensitive issues. It has been suggested to me that to describe an issue as 'sensitive' is to be somewhat disparaging. This, of course, is not my intention. Death, sexuality, drugs policy and animal experimentation are examples of issues that are sensitive for many students 
and many teachers are used to dealing respectfully with students when dealing with sensitive issues.

An advantage of shifting the discourse from controversy to sensitivity is that one shifts the focus from epistemology to pedagogy. One can be sensitive with someone in respect of an issue without implying that one shares the same perspective (or worldview) as the person to whom one is being respectful and considerate. Explicitly accepting the teaching of evolution as controversial, on the other hand, will be difficult for many science teachers as the distinction between this and evolution as controversial is a fine one and many science teachers are likely to see it as selling out to creationists (cf. Hermann, 2008).

Of course, my suggestion that teaching in this field be considered akin to the teaching of traditional sensitive issues does not absolve teachers (and relevant others such as curriculum designers and textbook authors-Williams (2008)), whatever their specialisms, from having as good a knowledge of the issues as they can. Mary Midgley (2007) points out that there is much to be said in initial teacher education for bringing 'together lecturers in science and in religious studies in pairs - of course after adequate training - and let them jointly teach classes that combine both sets of trainee teachers together' (p. 42). In my experience such joint teaching, though expensive and sometimes difficult to organise, can work well, so long as there is sufficient mutual trust between the lecturers.

In a school science lesson when teaching evolution there is much therefore to be said for allowing students to raise any doubts they have (hardly a revolutionary idea in teaching) and doing one's best in such circumstances to have a genuine scientific discussion about the issues raised. The word 'genuine' doesn't mean that creationism or intelligent design deserve equal time with evolution. However, in certain classes, depending on the comfort of the teacher in dealing with such issues and the make up of the student body, it can be appropriate to deal with these issues.

If questions about the validity of evolution or issues about creationism and intelligent design arise during science lessons they can be used to illustrate a number of aspects of how science works such as 'how interpretation of data, using creative thought, provides evidence to test ideas and develop theories'; 'that there are some questions that science cannot currently answer, and some that science cannot address'; 'how uncertainties in scientific knowledge and scientific ideas change over time and about the role of the scientific community in validating these changes' (science educators in England and Wales will recognise these phrases as standard ones in National Curriculum science though there is no reason why such teaching should not occur in any country).

Having said that, I don't believe that teaching about evolution, creationism or intelligent design, in whatever lesson, is always straightforward. Some students get very heated; others remain silent even if they disagree profoundly with what is said. The DCSF Guidance suggests: 'Some students do hold creationist beliefs or believe in the arguments of the intelligent design movement and/or have parents/carers who accept such views. If either is brought up in a science lesson it should be handled in a way that is respectful of students' views, religious and otherwise, whilst clearly giving the message that the theory of evolution and the notion of an old Earth / 
universe are supported by a mass of evidence and fully accepted by the scientific community'.

As a science educator I do believe in taking seriously and respectfully the concerns of students who do not accept the theory of evolution while still introducing them to it. While it is unlikely that this will help students who have a conflict between science and their religious beliefs to resolve the conflict, good science teaching can help students to manage it - and to learn more science. Creationism can profitably be seen not as a simple misconception that careful science teaching can correct, as careful science teaching might hope to persuade a student that an object continues at uniform velocity unless acted on by a net force, or that most of the mass of a plant comes from air. Rather, a student who believes in creationism can be seen as inhabiting a nonscientific worldview, that is a very different way of seeing the world. One very rarely changes one's worldview as a result of a 50 minute lesson, however well taught.

My hope, rather, is simply to enable students to understand the scientific worldview with respect to origins, not necessarily to accept it. We can help students to find their science lessons interesting and intellectually challenging without their being threatening. Effective teaching in this area can not only help students learn about the theory of evolution but help them better to appreciate the way science is done, the procedures by which scientific knowledge accumulates, the limitations of science and the ways in which scientific knowledge differs from other forms of knowledge.

Correspondence: Michael J. Reiss, Institute of Education, University of London, 20 Bedford Way, London WC1H 0AL, UK.E-mail: m.reiss@ioe.ac.uk.

\section{REFERENCES}

Aerts, D., Apostel, L., De Moor, B., Hellemans, S. Maex, E., Van Belle, H. and Van der Veken, J. (1994) World Views: From fragmentation to integration (Brussels, VUB Press). Available at http://www.vub.ac.be/CLEA/pub/books/worldviews.pdf. Accessed 31 January 2011.

Alexakos, K. (2009) Science and creationism: a response to Kenneth Tobin, Cultural Studies of Science Education, 4, pp. 495-504.

Allgaier, J. (2008) Representing Science Education in UK Newspapers: A case study on the controversy surrounding teaching the theory of evolution and creationism in science classes (Milton Keynes, Open University), unpublished $\mathrm{PhD}$ thesis. Available at http://kn.open.ac.uk/public/getfile.cfm?documentfileid=13255. Accessed 25 May 2009.

Atkins, P. (1992) Will science ever fail? New Scientist, 8 August, pp. 32-35.

Baker, S. (2003) Bone of Contention: Is evolution true?, $3^{\text {rd }}$ edn (Rugby, Biblical Creation Society). 
Barash, D. P. and Lipton, J. E. (2001) The Myth of Monogamy: Fidelity and infidelity in animals and people (New York, W. H. Freeman).

Barbour, I. G. (1990) Religion in an Age of Science: The Gifford Lectures 1989-1991, volume 1 (London, SCM).

Behe, M. J. (1996) Darwin's Black Box: The biochemical challenge to evolution (New York, Free Press).

Bennett, T. (2004) Pasts Beyond Memory: Evolution, museums, colonialism (London, Routledge).

Brickhouse, N. W. and Letts, IV, W. J. (1998) The problem of dogmatism in science education, in J. T. Sears and J. C. Carper (eds) Curriculum, Religion, and Public Education: Conversations for an enlarging public square (New York, Teachers College, Columbia University) pp. 221-230.

Bridges, D. (1986) Dealing with controversy in the curriculum: a philosophical perspective, in J. J. Wellington (ed.) Controversial Issues in the Curriculum (Oxford, Basil Blackwell), pp. 19-38.

California Department of Education (1990) Science Framework for California Public Schools (Sacramento, California Department of Education).

Chinsamy, A. and Plagányi, É. (2007) Accepting evolution, Evolution, 62, pp. 248254.

ChristianAnswers.Net: 2009, [Home page] http://christiananswers.net/. Accessed 31 January 2011.

Claire, H. and Holden, C. (eds) (2007) The Challenge of Teaching Controversial Issues (Stoke-on-Trent, Trentham).

DCSF (2007) Guidance on creationism and intelligent design. Available at www.teachernet.gov.uk/docbank/index.cfm?id=11890. Accessed 31 January 2011.

Dearden, R. F. (1984) Theory and Practice in Education (London, Routledge \& Kegan Paul).

Dembski, W. A. (1998) The Design Inference: Eliminating chance through small probabilities (Cambridge, Cambridge University Press).

Edis. T. (2007) An Illusion of Harmony: Science and religion in Islam (Amherst, NY, Prometheus Books).

Explore Evolution (2010). [Home page] http://www.exploreevolution.com/. Accessed 31 January 2011.

Gold, J. (2005) Does March of the Penguins support Intelligent Design theory? http://www.christiantoday.com/article/does.march.of.the.penguins.support.intellige nt.design.theory/4018.htm. Accessed 31 January 2011. 
Good, R. G., Trowbridge, J. E., Demastes, S. S., Wandersee, J. H., Hafner, M. S. and Cummins, C. L. (eds) (1992) Proceedings of the 1992 Evolution Education Research Conference (Baton Rouge, Louisiana State University).

Graebsch, A. and Schiermeier, Q. (2006) Anti-evolutionists raise their profile in Europe, Nature, 444, pp. 406-407.

Halstead, J. M. and Pike, M. A. (2006) Citizenship and Moral Education: Values in action (London, Routledge).

Hand, M. (2008) What should we teach as controversial? A defense of the epistemic criterion, Educational Theory, 58, pp. 213-228.

Hayward, A. (1985) Creation and Evolution: The facts and fallacies (London, Triangle).

Helms, M, (n.d.) Movie review: March of the Penguins http://www.christiananswers.net/spotlight/movies/2005/marchofthepenguins 2005.h tml. Accessed 31 January 2011.

Hermann, R. S. (2008) Evolution as a controversial issue: a review of instructional approaches, Science \& Education, 17, pp. 1011-1032.

Hess, D. E. (2009) Controversy in the Classroom: The democratic power of discussion (New York, Routledge).

Hokayem, H. and BouJaoude, S. (2008) College students' perceptions of the theory of evolution, Journal of Research in Science Teaching, 45, pp. 395-419.

Interacademy Panel on International Issues (2006) IAP Statement on the Teaching of Evolution. Available at http://www.interacademies.net/File.aspx?id=6150.

Accessed 31 January 2011.

Jackson, R. (2004) Rethinking Religious Education and Plurality: Issues in diversity and pedagogy (Abingdon, Routledge).

Jacquet, L. (2006) March of the Penguins (Washington, DC, National Geographic).

Johnson, P. E. (1999) The wedge: breaking the modernist monopoly on science, Touchstone, 12(4), pp. 18-24.

Jones, L. and Reiss, M. J. (eds) (2007) Teaching about Scientific Origins: Taking account of creationism (New York, Peter Lang).

Kitcher, P. (1983) Abusing Science: The case against creationism (Milton Keynes, Open University Press).

Koperski, J. (2008) Two bad ways to attack intelligent design and two good ones, Zygon, 43, pp. 433-449.

Kutschera, U. (2008) Creationism in Germany and its possible cause, Evolution: Education and Outreach, 1, pp. 84-86.

Lakatos, I. (1978) The Methodology of Scientific Research Programmes (Cambridge: Cambridge University Press). 
Lawes, C. (2009) Faith and Darwin: Harmony, Conflict, or Confusion? (London, Theos).

Levinson, R. (2006) Towards a theoretical framework for teaching controversial socio-scientific issues, International Journal of Science Education, 28, pp. 12011224.

McLaughlin, T. (2003) Teaching controversial issues in citizenship education, in A. Lockyer, B. Crick and J. Annette (eds) Education for Democratic Citizenship: Issues of theory and practice (Avebury, Aldershot), pp. 149-160.

Mabud, A. (1991) Theory of Evolution: An assessment from the Islamic point of view (Cambridge, Islamic Academy).

Mahner, M. and Bunge, M. (1996) Is religion education compatible with science education? Science \& Education, 5, pp. 101-123.

Marples, R. (ed.) (1999) The Aims of Education (London, Routledge).

Maynard Smith, J., and Szathmary, E. (2000) The Origins of Life: From the birth of life to the origin of language (Oxford, Oxford University Press).

Mercer, D. (2007) Capturing the educational potential of 'creation science debates', L. Jones and Reiss (eds) Teaching about Scientific Origins: Taking account of creationism (New York, Peter Lang), pp. 43-57.

Meyer, S. C., Nelson, P. A., Moneymaker, J., Minnich, S. and Seelke, R. (2009) Explore Evolution: The arguments for and against neo-Darwinism (Melbourne, Hill House).

Midgley, M. (2007) Impact No. 15: Intelligent Design Theory and other ideological problems (Philosophy of Education Society of Great Britain).

Miller, J. (2005) March of the Conservatives: Penguin film as political fodder http://www.nytimes.com/2005/09/13/science/13peng.html?ex $=1284264000 \&$ en $=3$ 6effea48de3fa22\&ei=5088\&partner $=r$ rssnyt\&emc $=$ rss. Accessed 31 January 2011.

Miller, J. D., Scott, E. C. and Okamoto, S. (2006) Public acceptance of evolution, Science, 313, pp. 765-766.

Moore, R. (2007) The history of the creationism/evolution controversy and likely future developments, in L. Jones and M. Reiss (eds) Teaching about Scientific Origins: Taking account of creationism (New York, Peter Lang), pp. 11-29.

Nagel. T. (2008) Public education and intelligent design, Philosophy \& Public Affairs, 36 , pp. 187-205.

National Academy of Sciences and Institute of Medicine (2008) Science, Evolution, and Creationism (Washington, DC, National Academies Press).

Negus, M. R. (2005) Islam and science, in C. Southgate (ed.) God, Humanity and the Cosmos, $2^{\text {nd }}$ edn revised and expanded as A Companion to the Science-Religion Debate (London, T \& T Clark), pp. 321-339. 
O'Brien, D. (2006) The Theory of Knowledge (Cambridge, Polity).

Osler, A. and Starkey, H. (2005) Changing Citizenship. Democracy and Inclusion in Education (London, Open University Press).

Parker, G. E. (2006) Creation: Facts of life-How real science reveals the hand of God (Los Angeles, CA, New Leaf Press).

Plimmer, I. (1994) Telling Lies for God: Reason vs creationism (Milsons Point, NSW, Random House).

QCA (2006) How can we answer questions about creation and origins? Learning from religion and science: Christianity, Hinduism, Islam and Humanism-Year 9 http://www.qcda.gov.uk/libraryAssets/media/qca-062728 y9 science religion master.pdf. Accessed 1 January 2011.

Reiss, M. J. (2007) What should be the aim(s) of school science education?, in D. Corrigan, J. Dillon and R. Gunstone (eds) The Re-emergence of Values in Science Education (Rotterdam, Sense), pp. 13-28.

Reiss, M. J. (2008a) Should science educators deal with the science/religion issue? Studies in Science Education, 44, pp. 157-186.

Reiss, M. J. (2008b) Teaching evolution in a creationist environment: an approach based on worldviews, not misconceptions, School Science Review, 90.331, pp. 4956.

Reiss, M. J. (2009) Imagining the world: the significance of religious worldviews for science education, Science \& Education, 18, pp. 783-796.

Scott, M. (2007) Rethinking Evolution in the Museum (Abingdon, Routledge).

Selkirk, D. R. and Burows F. J. (eds) (1987) Confronting Creationism: Defending Darwin (Kensington, NSW, New South Wales University Press).

Southgate, C., Negus, M. R. an d Robinson, A. (2005) Theology and evolutionary biology, in C. Southgate (ed.) God, Humanity and the Cosmos, $2^{\text {nd }}$ edn revised and expanded as A Companion to the Science-Religion Debate (London, T \& T Clark), pp.154-192.

Stradling, R. (1984) Controversial issues in the classroom, in R. Stradling, M. Noctor and B. Baines (eds) Teaching Controversial Issues (London, Edward Arnold), pp. $1-12$.

Stradling, R., Noctor, M. and Baines, B. (1984) An overview, in R. Stradling, M. Noctor and B. Baines (eds) Teaching Controversial Issues (London, Edward Arnold), pp. 101-116.

Tomatometer (2009) March of the Penguines (2005) http://uk.rottentomatoes.com/m/march_of_the_penguins/. Accessed 31 January 2011.

Truth in Science (2009) Resource pack, http://www.truthinscience.org.uk/site/content/view/43. Accessed 31 January 2011. 
Warner Independent Pictures (2010) March of the Penguins: Official site http://www.wbshop.com/March-of-the-

Penguins/1000018064,default,pd.html\#tcontentVideo. Accessed 1 January 2011.

Watson, D. C. C. (1975) The Great Brain Robbery (Worthing, Henry E. Walter).

Wellington, J. (ed.) (1986) Controversial Issues in the Curriculum (Oxford, Basil Blackwell).

Whitcomb, J. C. and Morris, H. M. (1961) Genesis Flood: The biblical record and its scientific implications (Philadelphia, Presbyterian \& Reformed Publishing).

Williams, J. D. (2008) Creationist teaching in school science: A UK perspective, Evolution: Education and Outreach, 1, pp. 87-95.

\footnotetext{
${ }^{1}$ http://www.truthinscience.org.uk/site/content/view/43/92/. Accessed 31 January 2011.

${ }^{2}$ http://www.exploreevolution.com/about the book.php. Accessed 31 January 2011.

${ }^{3}$ http://www.biology4all.com/biotutor.asp. Accessed 31 January 2011.
} 